\title{
MODE OF ACTION OF XANTHOCILLIN X MONOMETHYLETHER ON MULTIPLICATION OF NEWCASTLE DISEASE VIRUS IN CULTURED CELLS
}

\author{
(STUDIES ON ANTIVIRAL AND ANTITUMOR ANTIBIOTICS. XV)
}

\author{
Akira Takatsuki, Gakuzo Tamura and Kei Arima \\ Laboratory of Microbiology, Department of Agricultural Chemistry, \\ the University of Tokyo, Bunkyo-ku, Tokyo, Japan \\ (Received for publication February 14, 1969)
}

The mechanism of the action of xanthocillin $\mathrm{X}$ monomethylether (XME) on multiplication of Newcastle disease virus (NDV) in cultured cells was studied. The inhibitory effect of XME was exerted whenever the antibiotic $(15 \mu \mathrm{g} / \mathrm{ml})$ was added during the viral one-step growth cycle, and the effect could be reversed after removal of the antibiotic by washing. A lag period of approximately 5 hours was observed before the restoration of hemagglutinin synthesis had occurred. Pretreatment of host cells with XME for 7 hours and subsequent removal of the antibiotic did not affect velocity and yield of virus production. XME completely inhibited protein synthesis in both virus infected and mock-infected cells, however total actinomycin D-insensitive RNA synthesis was found to be practically the same in antibiotic-treated cells as in the control. Actinomycin D-insensitive RNA synthesized in the presence of $\mathrm{XME}$ was more heterogeneous than the control using methylated albuminkieselguhr (MAK) column chromatography. Antiviral activity of XME was compared with that of other antibiotics known to be inhibitors of protein synthesis. XME was found to be one of the best inhibitors among all compounds tested, due to its low cytotoxicity and low effective concentration in agar-diffusion plaque-inhibition tests.

During the course of an antiviral antibiotic screening program, mycelial acetone extract of two soil fungi was found to exert a remarkable antiviral activity on both RNA and DNA viruses using the agar-diffusion plaque-inhibition method. Three active principles were isolated in crystalline form and named xanthocillin $\mathrm{X}$ mono- and dimethylether and methoxy-xanthocillin $\mathrm{X}$ dimethylether (XME, XDE and $\mathrm{XTE})^{1)}$, respectively. Their structure was determined spectrometrically and found to be as shown

Fig. 1. Structures of xanthocillin X mono- and dimethylether, and methoxy-xanthocillin $\mathrm{X}$ dimethylether.

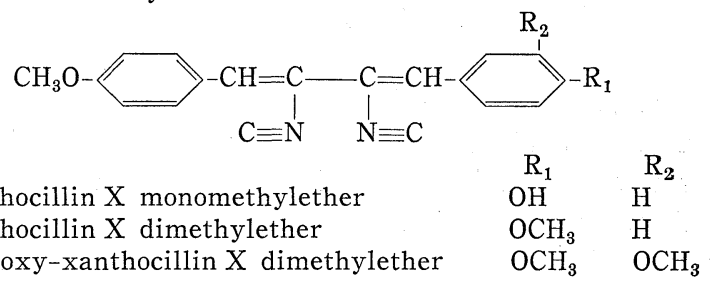
in Fig. 1 (manuscript in preparation). They have unique structures among fungal metabolites; each one possessing two isonitrile groups. A preliminary study on the action of these three antibiotics on multiplication of NDV showed that XME exerted the most pronounced inhibitory effect using both plate and tube assay methods 
among the three antibiotics; XME could completely suppress viral growth even when primary cultures of chick embryo fibroblasts (CEF) were infected at an input multiplicity of 50 plaque-forming units (PFU)/cell whereas the others only delayed the beginning of virus production ${ }^{1,2)}$. Further studies revealed that XME affected viral growth after adsorption and before maturation ${ }^{2}$.

A study of the mode of action of XME is reported in this paper. XME inhibits protein synthesis and its action can be reversed after its removal by washing. Actinomycin D-insensitive RNA synthesis was observed in the presence of XME and the velocity was nearly the same as in the control when the antibiotic was added 4 hours after infection. This result is in good accordance with the effect of other inhibitors of protein synthesis such as puromycin and 5-fluorophenylalanine ${ }^{3,4)}$. However, the elution profile of the RNA, synthesized in the presence of XME, was found to be more heterogeneous than the control using MAK column chromatography. Antiviral activity of XME, which was found to be based on inhibition of protein synthesis, was compared with that of other protein inhibitors, employing the agardiffusion plaque-inhibition method.

\section{Materials and Methods}

Virus-cell system. The Miyadera strain of NDV and primary cultures of CEF were employed, and the proliferation methods were the same as reported previously ${ }^{1}$.

Infection with NDV. Confluent monolayers of CEF in test tubes $(10 \times 200 \mathrm{~mm})$ or Petri dishes ( $90 \mathrm{~mm}$ in diameter) were washed twice with precooled $\left(5^{\circ} \mathrm{C}\right)$ medium. NDV was added at an input multiplicity of $50 \mathrm{PFU} /$ cell and allowed to be adsorbed at $5^{\circ} \mathrm{C}$ for 2 hours. Unadsorbed virus was removed by washing the cell sheets twice with prewarmed $\left(38.5^{\circ} \mathrm{C}\right)$ medium. The infected cells were re-fed with fresh prewarmed medium $(1 \mathrm{ml} / \mathrm{tube}$ or $10 \mathrm{ml} / \mathrm{dish}$ ) and incubated at $38.5^{\circ} \mathrm{C}$ (0 time). The same run was carried out with mock-infected controls.

Titration of virus production. Viral growth was followed by titration of hemagglutinin units (HAU) and/or PFU after three cycles of freezing-and-thawing in a dry ice-acetone bath ${ }^{2}$.

Examination of antiviral activity by agar-diffusion plaque-inhibition method. According to the method of Herrmann et al. ${ }^{5)}$, confluent monolayers of CEF in Petri dishes were infected with NDV to form about 3,000 plaques/dish. Paper disks (Toyo Roshi Co., Tokyo, Japan) impregnated with antibiotic solutions were placed on hardened overlayers of soft agar medium. After a 2-day incubation at $38.5^{\circ} \mathrm{C}$, the diameters of the cytotoxic zones caused by the drugs and the plaque-free antiviral zones were measured ${ }^{6}$.

Labeling with ${ }^{14} \mathrm{C}$-protein hydrolysates. Virus-infected and mock-infected cell sheets in test tubes were washed twice with prewarmed medium deprived of lactoalbumin hydrolysate and re-fed with fresh medium ( $1 \mathrm{ml} /$ tube). After a 30 -minute incubation period at $38.5^{\circ} \mathrm{C}$, the medium was replaced with the medium free of lactoalbumin hydrolysate and containing XME $(15 \mu \mathrm{g} / \mathrm{ml})$ as well as ${ }^{14} \mathrm{C}$-protein hydrolysates $(0.5 \mu \mathrm{C} / \mathrm{ml}, 54 \mathrm{mC} /$ $\mathrm{mAtom}$ carbon). They were further incubated at $38.5^{\circ} \mathrm{C}$. At the times indicated, bovine serum albumin $(200 \mu \mathrm{g} / \mathrm{ml})$ and cold $10 \%$ trichloroacetic acid (TCA) were added after three cycles of freezing-and-thawing of cells and medium in a dry ice-acetone bath in duplicate tubes. The tubes were chilled in an ice bath for 2 hours, and precipitates were collected on Millipore filters (HA type, Millipore Co., Massachusetts, U.S.A.) then washed three times with cold $10 \%$ TCA. The filters were mounted on metal planchets and radioactivity was counted after drying. 
${ }^{32} \mathrm{P}-\mathrm{Phosphate}$ incorporation and extraction of nucleic acids. All procedures of virus infection and growth were performed with the medium free of phosphate. XME (15 $\mu \mathrm{g} /$ $\mathrm{ml})$ and actinomycin $\mathrm{D}(2 \mu \mathrm{g} / \mathrm{ml})$ were added to infected cell cultures in Petri dishes or test tubes and carrier-free ${ }^{32} \mathrm{P}$-phosphate $(50 \sim 100 \mu \mathrm{C} / \mathrm{ml})$ was added after a 1 -hour treatment with the antibiotics. Incorporation of radioactivity was stopped by addition of ethylenediamine tetraacetic acid (EDTA) $\left(10^{-2} \mathrm{M}\right)$ and sodium dodecylsulfate (SDS) $(1 \%)$ or by chilling in an ice bath. For the measurement of total incorporation of radioactivity into RNA, cells and medium in duplicate tubes were fractionated by the SchmidiThANNHAUSER method ${ }^{7)}$ and radioactivity in the RNA fraction was counted after drying on metal planchets. Nucleic acids were extracted by shaking twice for 3 minutes with an equal volume of phenol-saturated $0.05 \mathrm{M}$ phosphate buffer ( $\mathrm{pH}$ 6.7). Two volumes of ethanol were added to the aqueous layers after addition of nucleic acids prepared from chick embryos by the SDS-phenol method as carriers. After standing at $-20^{\circ} \mathrm{C}$ overnight, precipitates were collected by centrifugation.

MAK column chromatography. MAK columns were prepared by the method of SueOKA and $\mathrm{CHENG}^{8)}$. Nucleic acids labeled with ${ }^{32} \mathrm{P}$, prepared as described, above were dissolved in $0.1 \mathrm{M} \mathrm{NaCl}-0.05 \mathrm{M}$ phosphate buffer ( $\mathrm{pH}$ 6.7) and loaded on the column. The absorbed nucleic acids were washed with $100 \mathrm{ml} 0.2 \mathrm{M}$ phosphate buffer and allowed to stand at $5^{\circ} \mathrm{C}$ for more than 10 hours. Standing at $5^{\circ} \mathrm{C}$ or at room temperature makes possible the separation of $18 \mathrm{~S}$ and $28 \mathrm{~S}$ ribosomal RNA, but $5^{\circ} \mathrm{C}$ is more recommendable in order to avoid a degradation during standing (manuscript in preparation). Elution of nucleic acids was carried out using linear gradient indicated and in each case elution was followed by measuring radioactivity and optical density at $260 \mathrm{~m} \mu\left(\mathrm{OD}_{260 \mathrm{~m} \mu}\right)$.

Counting of radioactivity. Radioactivizy of ${ }^{14} \mathrm{C}$ and ${ }^{32} \mathrm{P}$ in each sample was counted by drying an aliquot on a metal planchet and using a gas flow counter Aloka Model PS-3 or SC-7 (Japan Radiotelegraph Co., Tokyo, Japan).

Chemicals used. XME was prepared from a mycelial acetone extract of F-2081). Actinomycin D was a gift from Merck, Sharp and Dohme International, New York, U.S.A. Puromycin, cycloheximide, and streptomycin were products, respectively, of Lederle Laboratories, Pearl River, U.S.A., Kaken Kagaku Co., Tokyo, Japan, and Meiji Seika Kaisha, Tokyo, Japan. Helvolinic acid was isolated from a soil fungus in our laboratory. The other antibiotics (blasticidin S, tetracycline, kasugamycin, mikamycin A and B, kanamycin, chloramphenicol, fusidic acid, bottromycin and lincomycin) were obtained by the courtesy of Dr. N. Tanaka of the Institute of Applied Microbiology, University of Tokyo. SDS and bovine serum albumin were purchased, respectively, from Koso Chemical Co., Tokyo, Japan and Armour Pharmaceutical Co., Chicago, U.S.A. ${ }^{14}$ C-Protein hydrolysates (prepared from Chlorella vulgaris, $54 \mathrm{mC} / \mathrm{mAtom}$ carbon) and carrier-free ${ }^{32} \mathrm{P}-$ phosphate were obtained from the Radiochemical Centre, Amersham, England.

\section{Results}

Effect of addition time on NDV growth.

Confluent monolayers of CEF in test tubes were infected with NDV at an input multiplicity of $50 \mathrm{PFU} / \mathrm{cell}$. Viral growth was followed by titration of HAU after a 2-hour adsorption period. XME $(15 \mu \mathrm{g} / \mathrm{ml})$ was added at the times indicated in order to determine the relationship between time of addition and inhibitory activity on viral growth. XME displayed its activity whenever it was added during the viral one-step growth cycle. Complete inhibition of hemagglutinin (HA) synthesis was found already 1 hour after addition of the antibiotic (Fig. 2). 
Reversibility of the inhibitory action of XME.

XME $(15 \mu \mathrm{g} / \mathrm{ml})$ was added at zero hour and removed again by washing cell sheets in test tubes after various periods of treatment in order to examine the recovery of HA synthesis after its inhibition by the antibiotic (Fig. 3). The increased lag time before detectable onset of HA production, correlated with the duration of antibiotic treatment. No difference was observed in velocity and yield of HA synthesis of recovered cells after the removal of XME, compared with those of the controls. About 5 hours were required before detection of restoration of HA synthesis. The same effect was observed when the antibiotic was added during the viral exponential growth phase (Fig. 4). These results may indicate the preservation of an intact translation template during the antibiotic treatment. SchAEFER et al. ${ }^{9}$ observed that infected NDVRNA could serve as template for more than 7 hours.

Effect of pretreatment of CEF on viral growth.

In order to exclude the possibility that the lag period, observed prior to recovery of HA production after the removal of XME, was caused by the restoration of normal cell metabolism, CEF were pretreated with the antibiotic (15 $\mu \mathrm{g} / \mathrm{ml})$ for 7 hours before NDV
Fig. 2. Effect of time of addition of XME on virus multiplication.

Confluent monolayers of $\mathrm{CEF}$ in test tubes were infected with NDV (50 PFU/cell), and XME (15 $\mu \mathrm{g} / \mathrm{ml})$ was added at $0,1,4$ and 6 hours after infection. NDV multiplication in duplicate tubes was followed by titration of HAU and was compared with that in the absence of the antibiotic (negative control).

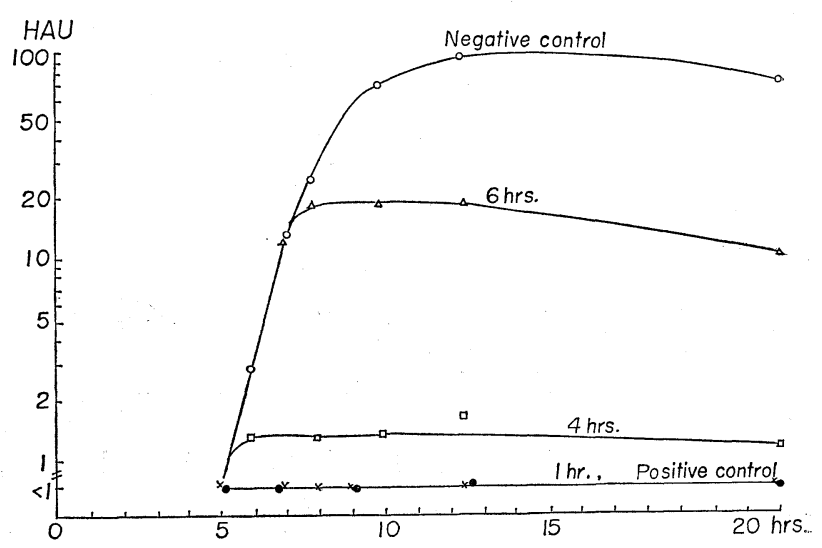

Fig. 3. Reversibility of the inhibitory action of XME $(15 \mu \mathrm{g} / \mathrm{ml})$ on NDV growth after removal of $\mathrm{XME}$ after infection.

Cell sheets in test tubes were infected with NDV (50 PFU/cell) and XME was added at zero hour. The antibiotic was removed by washing cell sheets twice at 1, 4 and 7 hours after application. Viral growth in the presence (positive control) and in the absence (negative control) of the antibiotic throughout the experiment was also tested. Viral multiplication was determined by titration of HAU and checked by PFU counting at 22 hours.

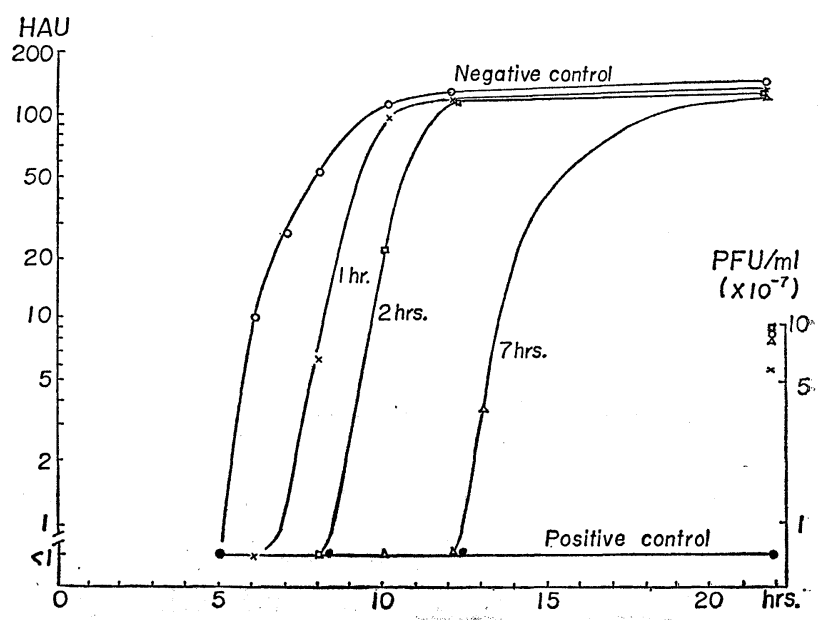


infection. No difference was detected in the kinetics of HA production between the antibiotic-treated and the control (Fig. 5).

Inhibitory action on protein synthesis in virusinfected and mock-infected CEF.

Effect of XME $(15 \mu \mathrm{g} / \mathrm{ml})$ on protein synthesis in NDVinfected and mock-infected cells was studied by measuring ${ }^{14} \mathrm{C}$-amino acids incorporation into the acid-insoluble fraction. Protein synthesis was partially suppressed in infected cells in comparison with non-infected control cells (Fig. $6 \mathrm{~A}$ and B), as a phenomenon also observed by ScholtisseK and RotT $^{3)}$ and BorognesI and WILSON ${ }^{10)}$. XME completely inhibited incorporation of radioactivity in both infected and mockinfected CEF. Approximately 1 hour was required before complete cessation of incorporation as measured by HA synthesis (Fig. 2).

Actinomycin D-insensitive RNA synthesis.

It is a well-known fact that NDV can multiply in the presence of actinomycin $\mathrm{D}$ and viral RNA synthesis can be unmasked by inhibition of cellular RNA synthesis
Fig. 4. Effect of periods of treatment of NDV-infected CEF with XME $(15 \mu \mathrm{g} / \mathrm{ml})$ on the reversibility of the antibiotic action. XME was added to infected (50 $\mathrm{PFU} /$ cell) cell cultures in test tubes and removed by washing twice at the times indicated. NDV growth in the above cells was compared with that in the presence (positive control) and absence (negative control) of the antibiotic throughout the experiment by titration of HA production.

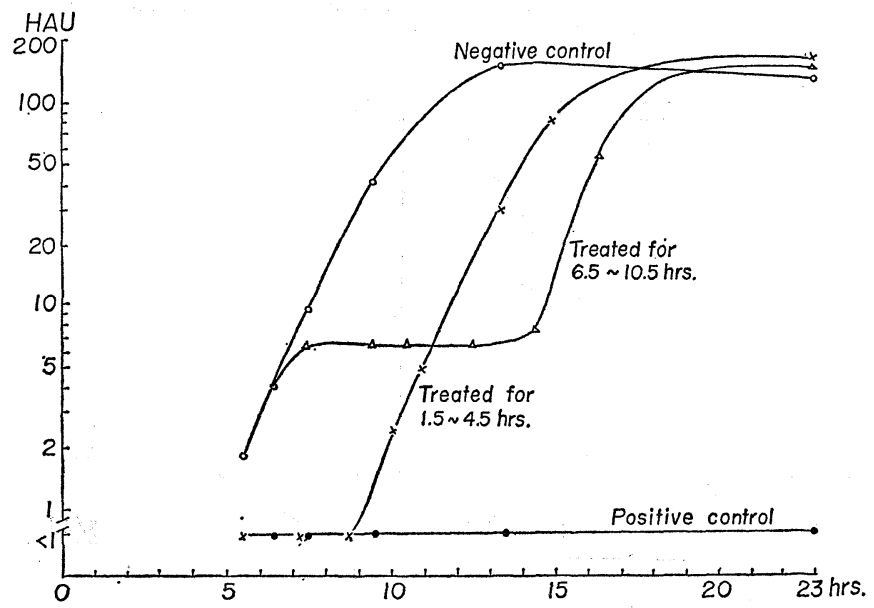

Fig. 5. Effect of pretreatment of cultured CEF with $\mathrm{XME}(15 \mu \mathrm{g} / \mathrm{ml})$ on NDV multiplication. Confluent monolayers in test tubes were pretreated with XME for 7 hours and the antibiotic was removed at the time of infection (50 PFU/cell). Viral growth in the pretreated cells in the absence (1) and presence (3) of the antibiotic throughout the experiment was followed by HAU titration and was compared with that in cells mock-treated with XME (2).

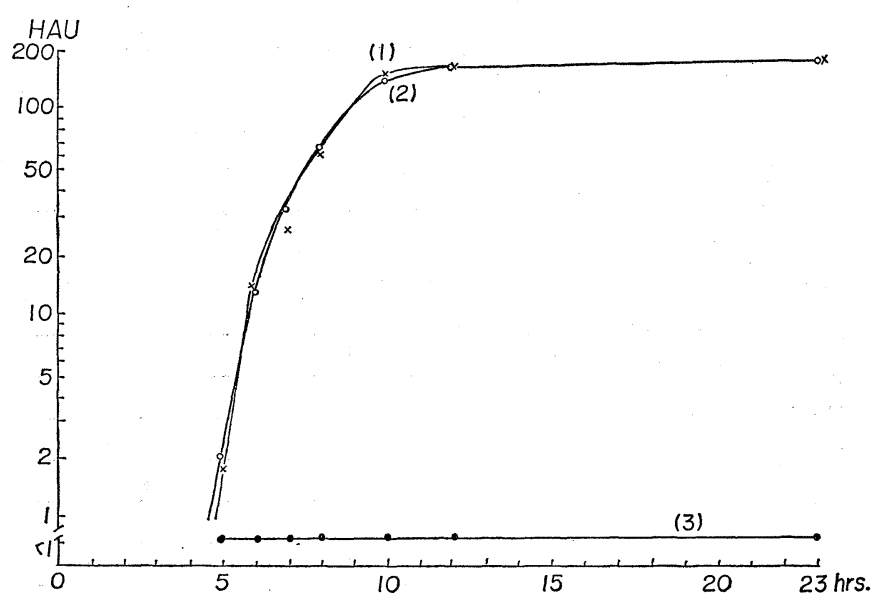
and containing actinomycin $\mathrm{D}$ but to a lesser extent than in the control of our system. Newly synthesized actinomycin D-insensitive RNA was observed in the presence of $\mathrm{XME}(15 \mu \mathrm{g} / \mathrm{ml})$ when it was added 4 hours after the infection, though 
Fig. 6. Protein synthesis in NDV-infected and mockinfected cells in the presence and absence of XME $(15 \mu \mathrm{g} / \mathrm{ml})$ was determined by measuring the incorporation of ${ }^{14} \mathrm{C}$-protein hydrolysates into acid-insoluble fraction. XME and protein hydrolysates were added at 5 hours after a 30-minute starvation for amino acids in the lactoalbumin hydrolysate-free medium. At the times indicated medium and cells in duplicate tubes were frozen and thawed in a dry ice-acetone bath three times, and $10 \%$ TCA-insoluble radioactivity held on Millipore filters was counted.
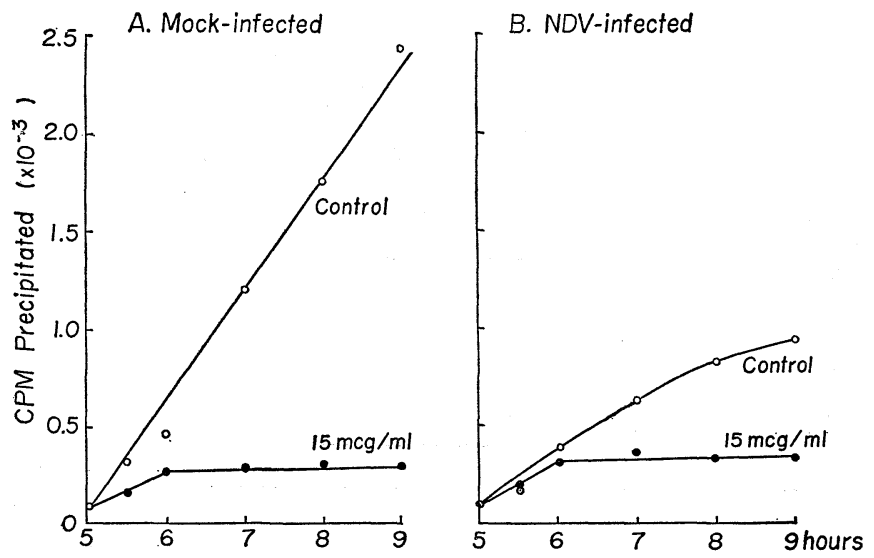

Fig. 7. Time course of NDV-RNA synthesis unmasked by actinomycin D $(2 \mu \mathrm{g} / \mathrm{ml})$ in the presence and absence of XME $(15 \mu \mathrm{g} / \mathrm{ml})$. Actinomycin D and XME were added to infected cell cultures in test tubes at 4 hours and ${ }^{32} \mathrm{P}$ phosphate $(50 \mu \mathrm{C} / \mathrm{ml})$ was added at 5 hours after infection. At the times indicated duplicate tubes were chilled in an ice bath and RNA was fractionated according to the method of SchmidT and Thannhauser. Radioactivity in RNA fractions was counted and expressed in per cent of that of the control at 22 hours after infection.

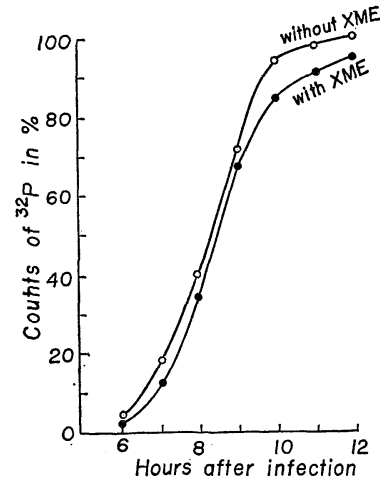

Table 1. Effect of antibiotics which inhibit protein synthesis on multiplication of

\begin{tabular}{|c|c|c|c|c|c|c|c|c|c|c|c|c|}
\hline \multirow{3}{*}{ Antibiotics } & \multicolumn{12}{|c|}{ Concentration } \\
\hline & \multicolumn{2}{|c|}{4,000} & \multicolumn{2}{|c|}{2,000} & \multicolumn{2}{|c|}{1,000} & \multicolumn{2}{|c|}{500} & \multicolumn{2}{|c|}{250} & \multicolumn{2}{|c|}{125} \\
\hline & $C T Z^{\mathrm{b})}$ & $\left.A V Z^{c}\right)$ & CTZ & $A V Z$ & CTZ & $A V Z$ & $\mathrm{CTZ}$ & $A V Z$ & $\mathrm{CTZ}$ & $A V Z$ & CTZ & $A V Z$ \\
\hline Cycloheximide & 37.0 & 40.0 & 23.8 & 35.9 & 17.0 & 33.9 & - & 30.9 & - & 28.2 & - & 27.0 \\
\hline Puromycin & N.T.d) & N.T. & N.T. & N.T. & 40.6 & - & 33.9 & 40.2 & 23.8 & 37.5 & - & 20.6 \\
\hline Blasticidin S & 31.6 & 40.8 & 23.0 & 32.8 & - & 29.0 & - & 20.8 & - & 17.9 & - & \pm \\
\hline Tetracycline & 20.0 & 31.5 & 13.7 & 24.8 & 12.5 & 20.3 & 11.0 & 17.2 & \pm & 16.2 & - & - \\
\hline Kasugamycin & - & 11.6 & - & - & - & - & - & - & - & - & - & - \\
\hline Mikamycin A & - & - & - & - & - & - & - & - & - & - & - & - \\
\hline Mikamycin B & - & - & - & - & - & - & - & - & - & - & - & - \\
\hline Mikamycin $\left.A, B^{e}\right)$ & 32.3 & 38.7 & 27.3 & 34.5 & 16.1 & 29.0 & 13.2 & 24.2 & 18. 6 & 22.5 & 18. 6 & 21.2 \\
\hline Chloramphenicol & - & - & - & - & - & - & - & - & - & - & - & - \\
\hline Kanamycin & - & - & - & - & - & - & - & - & - & - & - & - \\
\hline Fusidic acid & - & - & - & - & - & - & - & - & - & - & - & - \\
\hline Helvolinic acid & - & - & - & - & - & - & - & - & - & - & - & - \\
\hline Bottromycin & - & - & - & - & - & - & - & - & - & - & - & - \\
\hline Streptomycin & - & - & - & - & - & - & - & - & - & - & - & - \\
\hline Lincomycin & - & - & - & - & - & - & - & - & - & - & - & - \\
\hline
\end{tabular}

a) Antiviral activity of antibiotics was determined by the agar-diffusion plaque-inhibition method according to the procedure reported previously $\left.{ }^{6}\right)$

b) Cytotoxic zone caused by drugs. Expressed in zone diameter ( $\mathrm{mm}$ ).

c) Plaque-free antiviral zone expressed in zone diameter $(\mathrm{mm})$.

d) Not tested.

e) Mixture of mikamycin A and B (85:15). 
there was a complete inhibition of protein synthesis (Fig. 6). The total actinomycin D-insensitive viral RNA synthesis of XME-treated cells was nearly equal to that of the controls without XME (Fig. 7). Wilson and LoGERFo ${ }^{4)}$ and ScholtisseK and RoTT $^{3)}$ reported the same effect for puromycin and 5-fluorophenylalanine.

The viral RNA synthesized in the presence of actinomycin $\mathrm{D}$ and XME was analyzed on MAK column. Carrier-free ${ }^{32} \mathrm{P}(50 \mu \mathrm{G} / \mathrm{ml})$ was added after a 1-hour treatment with actinomycin $\mathrm{D}(2 \mu \mathrm{g} / \mathrm{ml})$ and XME $(15 \mu \mathrm{g} / \mathrm{ml})$ at a time when cellular nucleic acids and cellular and viral protein synthesis were almost completely inhibited. Pulse labeling was carried out for 5 hours. Newly synthesized and ${ }^{32} \mathrm{P}$-labeled viral RNA were extracted by SDS-phenol method and analyzed by passing through MAK column. Results of a representative test are shown in Fig. 8. Total incorporation of radioactivity into the RNA fraction was nearly equal for XME-treated cells and the control (Fig. 7). However the radioactivity eluted at the position of mature NDV-RNA (after 28S ribosomal RNA, unpublished data) was about one-third that of the control when infected cells were treated with XME. The residual radioactivity was found to be eluted at a lower salt concentration (ca. $0.4 \mathrm{M}$ ).

Antiviral activity of antibiotics which inhibit protein synthesis.

Many antibiotics have been reported to inhibit protein synthesis in bacteria and/ or animal cells, and some of them show specificity for either bacteria or animal cells. The mechanism of their action was reviewed by TANAKA ${ }^{12,13)}$. XME was found to be a potent inhibitor of protein synthesis (Fig. 6).

NDV determined by agar diffusion methoda)

\begin{tabular}{|c|c|c|c|c|c|c|c|c|c|}
\hline \multicolumn{10}{|c|}{$(\mu \mathrm{g} / \mathrm{ml})$} \\
\hline \multicolumn{2}{|c|}{62.5} & \multicolumn{2}{|c|}{31.3} & \multicolumn{2}{|c|}{15.6} & \multicolumn{2}{|c|}{7.8} & \multicolumn{2}{|c|}{3.9} \\
\hline CTZ & $\mathrm{AVZ}$ & $\mathrm{CTZ}$ & $\mathrm{AVZ}$ & $\mathrm{CTZ}$ & $A V Z$ & $\mathrm{CTZ}$ & $\mathrm{AVZ}$ & CTZ & AVZ \\
\hline- & 23.0 & - & 22.0 & - & 18.0 & - & 14.3 & - & - \\
\hline- & 18.7 & - & 16.3 & - & 11.5 & - & - & - & - \\
\hline- & - & - & - & - & - & - & - & - & - \\
\hline- & - & - & - & - & - & - & - & - & - \\
\hline- & - & - & - & - & - & - & - & - & - \\
\hline- & - & - & - & - & - & - & - & - & - \\
\hline- & - & - & - & - & - & - & - & - & - \\
\hline 13.5 & 19.7 & 11.2 & 14.0 & - & 11.8 & - & - & - & - \\
\hline- & - & - & - & - & - & - & - & - & - \\
\hline- & - & - & - & - & - & - & - & - & - \\
\hline- & - & - & - & - & - & - & - & - & - \\
\hline- & - & - & - & - & - & - & - & - & - \\
\hline- & - & - & - & - & - & - & - & - & - \\
\hline- & - & - & - & - & - & - & - & - & - \\
\hline- & - & - & - & - & - & - & - & - & - \\
\hline
\end{tabular}

Antiviral activity of protein inhibitors such as cycloheximide, puromycin, blasticidin $\mathrm{S}$, tetracycline, kasugamycin, mikamycin A and B, chloramphenicol, kanamycin, fusidic acid, helvolinic acid, bottromycin, streptomycin and lincomycin was tested by the agar-diffusion plaque-inhibition method (Table 1). Cycloheximide and puromycin are well-known inhibitors of viral multiplication, and they showed antiviral activity in this assay system. The cytotoxicity of puromycin for cultured cells was rather high. Its chemotherapeutic index in vitro, i.e., the ratio of the minimum inhibitory concentration for the maximum concentration tolerated by 
Fig. 8. Analysis of NDV-RNA synthesized in the absence (A) and presence (B) of $\mathrm{XME}(15 \mu \mathrm{g} / \mathrm{ml})$. Cell sheets in Petri dishes were infected with NDV at an input multiplicity of $50 \mathrm{PFU} /$ cell and labeling with ${ }^{32} \mathrm{P}(50 \mu \mathrm{C} / \mathrm{ml})$ was carried out for 5 hours after 1-hour treatment with the antibiotics as described in the legend to Fig. 7. Nucleic acids extracted by SDS-phenol method were analysed by MAK column chromatography (linear gradient of $0.4 \rightarrow 1.4 \mathrm{~m} / 350 \mathrm{ml}, 3.5 \mathrm{sec} / \mathrm{drop}, 4 \mathrm{ml} / \mathrm{tube}$ ).
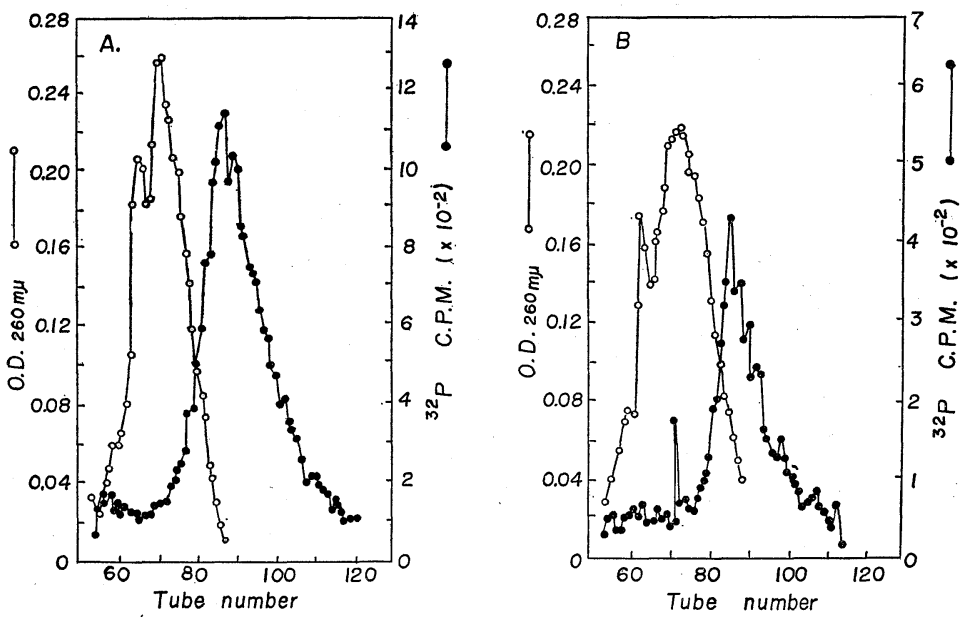

cultured cells, was 16 which is lower than that of $\mathrm{XME}^{1)}$ and of cycloheximide (Table 1). Blasticidin $S$ is reported to be active on plant viruses ${ }^{14,15,16)}$. It also inhibits NDV growth, but it was more toxic than puromycin and its chemotherapeutic index in this system was approximately 8. Mikamycin A and B had no action on both CEF and viral growth when administered individually, but their mixture (85:15) exerted high toxicity for cultured cells and produced a plaque-free antiviral zone outside the toxicity zone. Their synergistic action on bacterial growth has been reported ${ }^{17)}$. The inhibitory action on protein synthesis of chloramphenicol, kanamycin, fusidic acid, helvolinic acid, bottromycin, streptomycin and lincomycin is specific for bacterial synthesizing system and they are not effective on protein synthesis in mammalian cells (see reviews by TANAKA ${ }^{12,13)}$ ). All of them were also inactive on NDV growth in the agar-diffusion method and they displayed no cytotoxicity for cultured cells at the highest concentration examined $(4 \mathrm{mg} / \mathrm{ml})$.

\section{Discussion}

XME showed inhibitory action on protein synthesis in NDV-infected and mockinfected cells but had only a slight effect on actinomycin D-insensitive RNA synthesis. An accumulation of precursors of ribosomal RNA was observed in cultured cells in the presence of XME, and the antibiotic inhibited the conversion of the precursors to mature ribosomal RNA's requiring new synthesis of protein $(\mathrm{s})^{18)}$ (manuscript in preparation). These results may indicate that the inhibition of viral growth due to XME is a result of cessation of protein synthesis. However, a determination whether or not the inhibition of protein synthesis is the primary step of the action of XME requires further studies including an examination with cell-free protein synthesizing systems. The inhibitory action was displayed whenever the antibiotic was added during the viral one-step growth cycle (Fig. 1), and this may be a fact to be taken into consideration that the antiviral activity may be the result of the inhibition of protein synthesis. The effect of XME is reversible; viral growth (Figs. 2 and 3 ) and cellular protein synthesis (manuscript in 
preparation) is restored after removal of the antibiotic by washing.

Scholtisser and RotT ${ }^{3)}$ and Wilson and LoGerfo ${ }^{4)}$ reported that "early proteins", required for NDV-RNA synthesis, were synthesized upto 4 hours after the infection and addition of inhibitors of protein synthesis thereafter did not affect viral RNA synthesis. The same effect was observed concerning the total incorporation of radioactivity (Fig. 7). MAK column chromatography of the newly synthesized actinomycin D-insensitive RNA revealed that the RNA, synthesized in the presence of XME, was more heterogeneous and the radioactivity eluted at the position of mature NDV-RNA was less than that of the control and the residual radioactivity was found to be eluted at a lower salt concentration (Fig. 8). This may suggest the requirement of new or continuous synthesis of protein for completion of the lengthening of the NDV-RNA chain. However, another possibility exists that NDV-RNA synthesized in the presence of XME may be unstable and may degradate during extraction procedures. Studies in this direction are in progress.

$\mathrm{XME}$ was found to be a potent inhibitor of protein synthesis (Fig. 6), and its antiviral activity was compared with that of other antibiotics known to be protein inhibitors (Table 1). Among a number of antibiotics tested, XME, cycloheximide, puromycin and blasticidin $\mathrm{S}$ showed remarkable antiviral activity at concentrations where they displayed no cytotoxicity for cultured cells by the agar-diffusion method. The activity of XME and cycloheximide was superior to that of puromycin and blasticidin $S$ due to their low cytotoxicity. Tetracycline and a mixture of mikamycin A and B $(85: 15)$ also displayed antiviral activity, but they were very toxic for cultured cells at effective concentrations. Chloramphenicol, kanamycin, fusidic acid, helvolinic acid, bottromycin, streptomycin and lincomycin had no antiviral and cytotoxic effect at the highest concentration tested $(4 \mathrm{mg} / \mathrm{ml})$. This may be expected taking into consideration of their specificity of action on bacterial protein synthesizing systems. Mikamycin A and B also have the same specificity of action ${ }^{12)}$ and they were ineffective on viral growth when administered individually. However, a synergism was observed and a mixture of mikamycin A and B ( $85: 15$ ) exerted both cytotoxicity and antiviral activity at $31.3 \mu \mathrm{g} / \mathrm{ml}$. This synergism of mikamycin $\mathrm{A}$ and $\mathrm{B}$ is also known to occur in the case of the inhibitory effect on bacterial growth ${ }^{17)}$. Synergism in the antiviral and cytotoxic effects was more than 250-fold, a value far higher than synergism related to antibacterial activity.

\section{Ref erences}

1) Takatsuki, A.; S. Suzuki, K. Ando, G. Tamura \& K. Arima: New antiviral antibiotics; xanthocillin $\mathrm{X}$ mono- and dimethylether, and methoxy-xanthocillin $\mathrm{X}$ dimethylether. I. Isolation and characterization. (Studies on antiviral and antitumor antibiotics. V). J. Antibiotics $21: 671 \sim 675,1968$

2) Takatsuki, A.; G. Tamura \& K. Arima: New antiviral antibiotics; xanthocillin $\mathrm{X}$ monoand dimethylether, and methoxy-xanthocillin $\mathrm{X}$ dimethylether. II. Biological aspects of antiviral activity. (Studies on antiviral and antitumor antibiotics. VI). J. Antibiotics $21: 676 \sim$ 680, 1968

3) Scholtisseк, C. \& R. Rотт: Metabolic changes in chick fibroblasts after infection with Newcastle disease virus. Nature 206:729 730, 1965

4) Wilson, D. E. \& P. LoGerfo: Inhibition of ribonucleic acid sythesis in Newcastle disease virus-infected cells by puromycin and 6-azauridine. J. Bact. $88: 1550 \sim 1555,1964$

5) Herrmann, E. C., Jr.; J. Gabliks, C. Engle \& P. L. Perlman: Agar diffusion method for detection and bioassay of antiviral antibiotics. Proc. Soc. Exp. Biol. \& Med. 103 : 625 628, 1960

6) Arima, K.; A. Takatsuki, S. Suzuki, K. Ando \& G. Tamura: Antiviral activity of trichothecin. J. Antibiotics $21: 158 \sim 159,1968$

7) Schmidt, G. \& S. J. Thannhauser: A method for the determination of deoxyribonucleic acid, ribonucleic acid, and phosphoproteins in animal tissues. J. Biol. Chem. 161: 83 89, 1945

8) Sueoka, N. \& T. Y. Cheng: Fractionation of nucleic acids with the methylated albumin column. J. Mol. Biol. 4 : 161 172, 1962 
9) Schaefer, W.; L. Pister \& R. Schneider: Analysis of the mechanism of production of Newcastle disease virus (NDV) with the aid of different inhibitors. Zeitschr. Naturforsch. B22 : 1319 1330, 1967

10) Bolognesi, D. P. \& D. E. Wilson : Inhibitory proteins in the Newcastle disease virus-induced suppression of cell protein synthesis. J. Bact. $91: 1896 \sim 1901,1966$

11) Kingsbury, D. W.: Use of actinomycin D to unmask RNA synthesis induced by Newcaslte disease virus. Biochem. Biophys. Res. Commun. $9: 156 \sim 161,1962$

12) TANAKA, N.: Inhibition of protein synthesis by antibiotics. Protein, Nucleic Acid \& Enzyme $10: 1321 \sim 1329,1965$

13) Tanaka, N.: Mechanism of protein synthesis inhibition by antibiotics. Protein, Nucleic Acid \& Enzyme $13: 808 \sim 818,1968$

14) Kitani, S. \& A. Kiso: Studies on the chemical prevention of rice spot disease. Ann. Phytopathol. Soc. Jap. $28: 293,1963$

15) Hirai, T. \& T. Shimomura: Blasticidin $S$, an effective antibiotic against plant virus multiplication. Phytopathol. $55: 291 \sim 295,1965$

16) Hirai, T.; A. Hirashima, T. Itoh, T. Takahashi, T. Shimomura \& Y. Hayashi: Inhibitory effect of blasticidin $S$ on tobacco mosaic virus multiplication. Phytopathol. $56: 1236 \sim 1340$, 1966

17) Tanaka, N.; N. Miyairi, K. Watanabe, N. Shinjo, T. Nishimura \& H. Umezawa: Biological studies on mikamycin. II. Laboratory investigations of mikamycin A and mikamycin B. J. Antibiotics, Ser. A $12: 290 \sim 297,1959$

18) Tamaoki, T. \& G. C. Mueller: The effects of actinomycin D and puromycin on the formation of ribosomes in HeLa cells. Biochim. Biophys. Acta $108: 73 \sim 80,1965$ 